\title{
Assessment that matters: The transformative potential of narrative assessment for students with special education needs
}

\author{
Missy Morton, Trish McMenamin, \\ Geoff Moore and Sue Molloy
}

\begin{abstract}
This paper suggests The New Zealand Curriculum Exemplars for Learners with Special Education Needs and the accompanying booklet, Narrative Assessment: A Guide for Teachers, can potentially transform the ways we think about teaching, learning, curriculum, pedagogy and assessment for the group of students considered most likely to be learning within level 1 of The New Zealand Curriculum for most of their time at school. The complex relationship of beliefs and practices around disability, curriculum, pedagogy and assessment are described. These beliefs and practices are the context for the development of the exemplars. The paper concludes with cautions and possibilities for the exemplars.
\end{abstract}

\section{Introduction}

The New Zealand Curriculum Exemplars for Learners with Special Education Needs and the accompanying booklet, Narrative Assessment: A Guide for Teachers (Ministry of Education, 2009a, 2009b), were developed to support teachers working with students "learning longterm at level 1" in The New Zealand Curriculum (Ministry of Education, 2007). We (the authors of this paper) were the project leaders in Education Plus, University of Canterbury, and were contracted by the Ministry of Education in 2007 to research and develop the exemplars and the guide. 
In its call for proposals to develop these exemplars, the Ministry of Education noted research reporting that some teachers believed that neither The New Zealand Curriculum nor most forms of assessment used in schools were relevant to the target group of students (McMenamin et al., 2004).

Danforth, Taff and Ferguson (2006) have explored shifts in beliefs about curriculum for students with special education needs in the US context. They highlight the relationship between curriculum and expectations for learning:

Curriculum comes into play only when teaching is attempted, and teaching is attempted only when learning is thought possible. Only then does the question of 'What do I teach?' arise. So, before a curriculum or 'course of study' becomes relevant, there must be a presumption that learning can occur. However, it is precisely this presumption that was late to emerge in the history of the education of children with disabilities ... Even today, when the federal mantra is to have 'No Child Left Behind' and the legislative mandate is that all children can learn and are, therefore, entitled to a 'free, appropriate public education,' the course of study for students with disabilities is often governed in practice by a system of presumptive labels that determine what will be taught, by whom, and in what type of educational setting. (p. 1)

Skidmore (2002) describes a similar UK legacy of exclusion, followed by grudging inclusion, predicated on beliefs about the educability of some and the enduring ineducability of others. It may be that some New Zealand teachers share many of the assumptions of US and UK educators. That is, that some students can only learn a very few things, and they need to be taught these very few things in very different ways to other students: "Failing to see students as capable and competent learners creates barriers to successful inclusive education for some children, limiting their access to the curriculum" (Morton \& McMenamin, 2011, p. 109). Low expectations for this group of students are grounded in a generalised and deficit view of disability.

In this paper we describe the development of The New Zealand Curriculum Exemplars for Learners with Special Education Needs and Narrative Assessment: A Guide for Teachers. We discuss some of the ways using 
narrative assessment has changed the ways teachers see their relationships with students "learning long-term at level 1". We suggest that narrative assessment can transform the way teachers see their students with special education needs. In the first part of the paper, we describe the context for the development of the exemplars. This context includes the experiences of students, their families and their teachers; research on curriculum and assessment for this group of students; and approaches to thinking about teaching, learning, curriculum and assessment. In the second part of the paper we present an overview of the process of the development of the exemplars. We discuss some of the important outcomes of the project. The paper concludes with cautions and possibilities for the transformative potential of narrative assessment.

\section{Context: Assessment, disability and special education}

The history of educational assessment is grounded in the psychology of the individual, with an emphasis on identifying innate, immutable characteristics and abilities or disabilities (e.g., Brantlinger, 2000; Broadfoot, 2007; James, 2006). Assessment of the individual with disabilities continues to be a key feature in the experiences of disabled students and their families internationally as well as in New Zealand.

Individual assessment of children with disabilities is often a high-stakes activity in the US. It can be very important to get the "right" diagnosis as this can determine both educational placement and access to resources. Placement decisions - where a student with disabilities is entitled to go to school in a particular school district—are largely dependent on diagnostic assessment. In the UK a similar process is known as statementing. A statement is a legal document issued by the Local Education Authority, which sets out the learning and educational needs of an individual child and specifies who will provide what, where and when and how. (See, for example, http://www.shropshire.gov.uk/leachildrensservices.nsf/viewAttachments/ SEWS-6TJCZY/\$file/SEN\%20statementing\%20process.htm)

In contrast, since the Education Act 1989, families in New Zealand have been legally entitled to enrol their children at their local school. This legislative entitlement distinguishes New Zealand from the US and the 
UK. In New Zealand, assessment is nevertheless required for access to resources. While decisions about funding individual children are not based on a diagnostic label per se, the application process requires families and educators to describe in detail the kinds of support needed for a student to be able to access the curriculum (the Ongoing Resourcing Scheme, or ORS; http://www.minedu.govt.nz/NZEducation/EducationPolicies/ SpecialEducation/ServicesAndSupport/OngoingResourcingScheme. aspx). Applicants need to justify the level of support they are applying for. The justification typically consists of a detailed description of all of a child's or young person's problems, failures or deficits. Parents consistently describe this process as demoralising and demeaning, particularly if they have not been successful in their funding application (MacArthur, 2005; Macartney, 2010; Macartney \& Morton, in press).

Studies in New Zealand (Gordon \& Morton, 2008; Kearney, 2008; McMenamin et al., 2004; Millar \& Morton, 2007) as elsewhere report that teachers believe they have not had the training necessary to include all students in their classroom. Brantlinger (2000) and Slee (2011) suggest that teachers get this misunderstanding through the way that differences are presented to student teachers; as if some differences are so far beyond the ken of ordinary teachers that only highly qualified and specialised professionals are able to identify (diagnose), assess and teach children with these differences. This is a view of difference, including disability, that pathologises difference; that explains students' differences (from a privileged norm) in terms of deficit (Macartney \& Morton, in press). We are not suggesting that professionals in education-related fields (such as speech-language therapy, psychology, physiotherapy, occupational therapy) have no place developing educational goals and/or strategies for students. However, we are arguing that input from education-related professionals is not a replacement for teacher knowledge of curriculum and curriculum assessment.

\section{Assessment, curriculum, pedagogy, disability and special education}

Changing, and contested, understandings of assessment, curriculum and pedagogy highlight the interrelatedness of these concepts. Broadfoot 
(2007) argues that assessment models "work to shape the way people think about and practice education" (p. 24). Hatherly and Richardson (2007) claim "We can only transform curriculum and pedagogy by also transforming the way we assess learning" (p. 51). Cowie (2009) describes "the dynamic interaction that exists between assessment, curriculum, teaching and learning" (p. 48).

A useful summary of views of teaching, learning, curriculum and the roles of students and teachers is provided by Smith and Barr (2008). For example, when the "curriculum is viewed as fact", then "learning = being taught". The "teacher is the expert" whose role it is to "impart new knowledge, skills and concepts". Learning is understood as being "individual and affected by ability which is seen as fixed". "Learners acquire new knowledge in predictable and manageable stages", and the "cognitive dimension is stressed" (p. 408). These are the views of learning that underpin traditional forms of educational measurement and assessment and that are rewarded in traditional measures of educational achievement (Gipps, 1994; Hipkins, 2007). These are also the views of learning that underpin most traditional educational practices for students with special education needs (Macartney, 2010; Macartney \& Morton, in press; Morton, in press).

Smith and Barr (2008) describe two other alternatives to "curriculum viewed as fact" (p. 408), both drawing on sociocultural understandings of learning and knowledge as negotiated and constructed through interaction. When the focus is on the constructed knowledge of the individual learner, the teacher is seen as more of a facilitator, guiding students through "curriculum as activity" as members of a community of (individual) learners. When teachers and students are all learners coconstructing knowledge, participating equally in a learning community, the emphasis shifts to "curriculum as inquiry". These more open-ended understandings of teaching, learning and curriculum are also evident in Skidmore's (2002) discussions of pedagogical discourse.

Skidmore (2002) illustrates how understandings of difference shape pedagogy. He describes two discourses of pedagogy: a discourse of inclusion and a discourse of deviance. These discourses are summarised 
in his "Table 1: Two Forms of Pedagogical Discourse" (p. 120). Each discourse can be recognised by how it frames five dimensions. These dimensions are: the educators' views of students' educability (the ability to learn); how educators explain educational failure; how schools respond to students who need support; educators' theories of teaching expertise; and educators' views of curriculum. Skidmore's list of dimensions shows that views of pedagogy cannot easily be separated from views of difference, curriculum, learning and so on. For example:

Where the discourse of deviance ascribes difficulties in learning to individual pathology, then, the open-ended view of educability associated with the discourse of inclusion directs attention instead to the quality of the human relationship between the tutor and the learner, and invites us to reflect on the contribution that aspects of school organization, curriculum and pedagogy make to producing student failure and disaffection. (Skidmore, 2002, p. 126)

Skidmore draws extensively on Vygotsky and a sociocultural view of teaching and learning in developing his pedagogical discourse of inclusion.

Paugh and Dudley-Marling (2011) describe how deficit thinking, the "unrelenting focus on what students cannot do" (p. 820) impacts teachers' sense of what they can accomplish. Narrow views of appropriate curriculum, a functional curriculum of self-help skills, appropriate behaviour and/or a much-watered-down version of academic curriculum typically result. As Cowie and Carr (2009) have noted, assessments are a means by which competence and competent learners are constructed. If we consider the views of teaching and learning described by Smith and Barr (2008), we might expect that, when teachers see "learning = being taught" then these teachers have difficulty seeing themselves as teachers when they do not view as learners some of the children and young people in their classrooms (Millar \& Morton, 2007; Morton \& McMenamin, 2011).

A number of authors have noted the difficulties, and successes, teachers in early childhood, primary and secondary settings experience when trying to take up sociocultural perspectives of curriculum, pedagogy and assessment (e.g., Cowie, 2009; Cullen, 2003; Dunn, 2004; Hill, 2003, 2009; Hipkins, 2009; Nuttall, 2003; Turnock, 2009; Willis, 2010). 
Cowie's (2009) study describes in detail an example of a teacher using interactive formative assessment during a discussion of science in a primary classroom. Her analysis of the interactions between students and teacher showed the

... complex contextualised nature of teacher assessment decision-making processes. The teacher's interpretations and actions were shaped and constrained by her confidence in her understanding of the science content, her confidence that she had the skills to guide the class to a consensus and her confidence the students would be able to contribute pertinent ideas and had the skills to discuss to consensus. (p. 52)

This analysis suggests that, in order for teachers to move away from more prescribed forms of teaching and assessment, teachers need both confidence in their own skills and knowledge and in their students' skills and knowledge.

The above discussion describes enmeshed views of difference, teaching and learning, curriculum, pedagogy and assessment that seem to weave a web of limited views, entangling students and teachers alike. Assessment then is focused on what students cannot do, or only looks for a much more narrow and constrained view of possible accomplishments-in turn shaping, and shaped by, curriculum, approaches to teaching, views of learning and constructions of students as learners.

\section{The development of The New Zealand Curriculum Exemplars for Learners with Special Education Needs}

The New Zealand Curriculum Exemplars for Learners with Special Education Needs was a project commissioned by the New Zealand Ministry of Education in 2007.

The scope of the guide and the exemplars was to be for all teachers whose classes include students who, throughout most of their time at school, are working within level 1 of The New Zealand Curriculum.

The contract for the work stipulated the following outcomes:

- raise expectations for the group of students as active learners 
- show that The New Zealand Curriculum is relevant for all students

- focus on assessment of the key competencies within the context of the learning areas in The New Zealand Curriculum

- illustrate an approach to assessment that could capture the complexity of learning that happens in the context of relationships (a sociocultural perspective on teaching and learning).

The project team consisted of curriculum and assessment facilitators working in Education Plus (the teacher professional learning arm of the College of Education at the University of Canterbury) as well as academics and teacher educators with backgrounds in assessment and inclusive education. The project advisory team included a parent of children with special education needs, a Resource Teacher of Learning and Behaviour who had also worked as a teacher educator, and a teacher educator from another university. During the development and review of the exemplars and Narrative Assessment: A Guide for Teachers there were multiple external evaluations and critique of both content and form. The external evaluators were teacher educators with recognised expertise in curriculum, assessment, pedagogy, inclusive education and teacher professional learning in early childhood, primary and secondary settings. Across the various roles and teams in the development of the exemplars and the guide were academic and professional learning staff from all of the six New Zealand universities with a college, school or faculty of education.

The curriculum and assessment facilitators from Education Plus were not special educators. Their areas of expertise included a deep knowledge of The New Zealand Curriculum and the principles and practices of assessment for learning, or formative assessment. A number of the facilitators also had previous experience of working with early childhood educators and primary teachers developing the use of Learning Stories as part of regular assessment practices.

In the exemplars project, the facilitators worked alongside 26 classroom teachers (the majority in "regular" classrooms) to develop the curriculum exemplars. The facilitators and teachers met regularly over the 2 years of exemplar development to share readings that challenged traditional notions of disability, curriculum and assessment. The readings also provided support in developing a sociocultural framework to guide the 
development of the exemplars. We also drew extensively on the principles and vision of the then newly released The New Zealand Curriculum (Ministry of Education, 2007).

This 2007 document combines relatively traditional individualistic views of curriculum and explicitly sociocultural understandings of curriculum and pedagogy. The subject or learning areas were slightly expanded, but continue to be framed and presented in a matrix of (presumably) increasing levels of difficulty. Each curriculum area is presented as a relatively standalone subject. This new curriculum also introduced the key competencies. The five competencies are thinking, managing self, participating and contributing, using language, symbols and texts and relating to others. The key competencies draw on knowledge, attitudes and values. They are both "a means to an end and a valued educational outcome" (Ministry of Education, 2007, p. 12). The New Zealand Curriculum describes how key competencies involve the learner in engaging personal goals, other people, community knowledge and values, cultural tools and the knowledge and skills found in learning areas. "People use these competencies to live, learn, work and contribute as active members of their communities" (Ministry of Education, 2007, p. 12).

In our regular meetings we explored and considered what these new aspects of The New Zealand Curriculum meant for classroom practices and assessment. We shared, critiqued and workshopped the exemplars and the guide to narrative assessment. The 26 classroom teachers wrote most of the narratives of learning within the exemplars. Some of the narratives were written by teacher aides working with the 26 teachers. A few narratives were written by parents. Together the teacher-writers and the facilitators explored the narratives of learning and developed frameworks to make sense of the learning teachers were now noticing. Morton and McMenamin (2011) provide a more detailed description of the project. The Ministry of Education published the Curriculum Exemplars and the Guide to Narrative Assessment in 2009 (the resources can be found online at www.throughdifferenteyes.org.nz). The guide describes in detail what can be found within each exemplar, and how the sections of each exemplar link to the learning areas, key competencies and effective pedagogy within The New Zealand Curriculum. 
Each exemplar consists of a number of narratives that describe who and what has been noticed, recognised and responded to by the writer. The exemplar is then presented with three key aspects highlighted from the collection of narratives: the key competencies, the learning area(s) that provide the context for showing learning in the key competencies and the elements of effective pedagogy that provided the opportunities for students to show their knowledge, understandings and skills.

In this project we were particularly interested in approaches to assessment that focused on noticing students' competence. We built on the work of Carr and colleagues who developed the narrative approach to assessment (Carr, 2001; Cowie \& Carr, 2009): "We take the view that learning and development, rather than being primarily about individual achievement, is distributed over, stretched across, people, places and things" (Cowie $\&$ Carr, 2009, p. 105). We were interested in supporting teachers to pay attention to the contexts that supported students to show that they were competent; more importantly, teachers began to appreciate their role in facilitating those contexts and opportunities for students to show what they knew and what they could do, to demonstrate their learning. Teachers could more readily recognise that students were showing evidence of learning, and that this learning could be directly linked to the subject areas of The New Zealand Curriculum.

\section{Some examples from these narratives}

There were a number of important outcomes from the project. The exemplars clearly show that narrative assessment was fostering students' identities as learners. Through making their learning visible and strengthening links to the curriculum, teachers had raised expectations for this group of students. Where individual Learning Stories or narratives are written for a more intimate audience of student, family and educators, the exemplars were written for an audience of strangers. Each exemplar begins with a description of the student and the context for their learning. We had many discussions about what should be included in these descriptions. The main area for debate was whether or not the section should include any diagnoses or labels. One expressed concern was that any focus on a label might detract from the student's achievements. 
Another concern was that if labels or diagnoses were omitted, readers might assume that the students in the exemplars were not comparable to the students in their own classrooms or experiences. The beginning of the introduction to Molly in Molly Makes Her Way illustrates this tension:

Molly is lots of fun. She prefers one-to-one attention from an adult at activities and will often leave an activity if other children come near or try to join. Molly loves music and movement and enjoys using the computer.

Molly started school this year and attends her local primary school. She is in a classroom of 16. Molly's strengths are her fascination with numbers and letters and her strong interest in books. Her school receives ongoing and reviewable resourcing schemes (ORRS) ${ }^{1}$ funding for Molly. She has global developmental delay and autism. Molly has motor planning difficulty, which means she needs support to work through a series of steps to complete a task. Molly has hyperlexia (a precocious ability to read words) but difficulty in understanding verbal language.

(http://www.inclusive.org.nz/throughdifferenteyes/exemplars/molly-makesher-way)

The two paragraphs above both lead with positive statements about Molly-how others find her ("fun"), and her strengths and interests ("loves music", "strong interest in books"). Her identified needs are, in the main, stated in constructive terms ("prefers one-to-one attention", "needs support to work through a series of steps to complete a task"). The description about the funding source (ORRS) the school uses to pay for her support, and the diagnostic terms ("global developmental delay and autism", "hyperlexia") cover a wide range of characteristics, only some of which might be relevant to knowing Molly, the individual child in this set of stories. Each narrative of learning focuses on what the educators (writers) are coming to know about Molly's strengths and interests (with a very "local" audience). The exemplars, on the other hand, are aimed at a broader audience who, it is hoped, will be able to make connections between the students and classrooms described in the exemplars and their own students and classrooms.

In another exemplar, Aaliyah's Learning Through Mathematics, Aaliyah's teacher describes first what she noticed about Aaliyah:

For the last two weeks we have been talking about shapes in the context of our geometry unit. 
Today, Aaliyah was in a small group that went to look for shapes out in the playground. She quietly and independently went on her search and then called out enthusiastically 'I have found a shape!' She was able to identify the shape she had found as a circle and to tell her peers that it had one side.

The next day Aaliyah was very keen to write about her shape at writing time. She sought the help of the student teacher, who helped her to write about the circle she had found.

(http://www.inclusive.org.nz/throughdifferenteyes/exemplars/aaliyahslearning-through-mathematics/x-learning-stories/story1)

The above description also illustrates that the teacher recognised this as learning. The importance to both the teacher and to the student is illustrated in the subsequent teacher analysis:

Analysis: What learning is happening here?

Aaliyah showed me that she is able to work outside in a constructive and positive way. This is amazing growth for Aaliyah, as working outside has often resulted in her running away from the group. Now that she has demonstrated this ability, I will be more able to use opportunities to use the playground as a teaching resource.

(http://www.inclusive.org.nz/throughdifferenteyes/exemplars/aaliyahslearning-through-mathematics/x-learning-stories/story $1 /$ review)

In the above example, the teacher comments that the student has "demonstrated this ability". In our conversations about teacher experiences, there were also comments about how teachers had to sometimes learn to recognise the learning and abilities their students were demonstrating. The teacher also comments on what she has learned: to use the playground more often as a context for learning.

Some of the exemplars ask specifically what the teacher has learned from the student. In the exemplar Tom Gets 'Play', the teacher poses the following question for reflection:

What has Tom taught the adults working/living with him?

Tom is teaching us that he can choose to play with others. He is showing us that he knows how to get the toys he wants.

(http://www.inclusive.org.nz/throughdifferenteyes/exemplars/tom-gets-play/ $\mathrm{x}$-learning-stories/story $1 /$ next-steps) 
In this exemplar, the student and teacher are both learners, learning from and with each other.

The teachers on the project described the assessment as meaningful, providing them with valuable information to reflect on their teaching and to consider next steps for students' learning. It supported building positive relationships with families through valuing families' input (because learning also happens outside of the classroom and school) and providing families with stories that celebrated students' learning.

Our experiences on this project were consistent with those reported by other writers looking at the conditions that shape teachers' understanding and enacting sociocultural perspectives on curriculum, pedagogy and assessment. Willis (2010), for example, notes "Within the family of sociocultural theoretical perspective, learning is viewed as social participation within a community of practice" (p. 65). Assessment for learning becomes "participative pedagogy", where teachers and students are learning from and with each other.

\section{Discussion: Cautions and possibilities}

As a teacher, the question of 'what is to be done' with respect to others (a particular child, or a group) depends on who I think the Other is, and who I am in relation to that person. (Smith, 2004, p. 459)

Traditionally, assessment for disabled students and their families has been about determining who the Other is, with a focus on diagnosis and/ or specifying deficits. Once the Other had been named, this traditional approach to assessment went on to set out what should be done with the Other, with a focus on prescribing the appropriate treatment including: what can be learned and how it must be taught, who should do the teaching, how often, where it would best be done and how it would be known if performance had improved (Brantlinger, 2000; Graham, 2008; Macartney, 2009; Morton, in press; Valle \& Connor, 2011).

Assessment is clearly implicated in the ways we identify our students; deciding whether or not they are Other to our "we". More than this, assessment is implicated in the ways we identify our colleagues, our 
students' families and ourselves. Smith (2004) reminds us that what we decide to do need not follow automatically from a particular label, or from a student behaving in ways we do not expect. We are reminded to think about our decisions around curriculum, pedagogy and assessment; to challenge assumptions that suggest that some students can only learn in certain ways, and only be taught certain things, and that we know this from particular kinds of assessment.

The development of The New Zealand Curriculum Exemplars for Students with Special Education Needs has shown us that it is indeed possible to transform the ways we think about teaching, learning, curriculum, pedagogy and assessment for the group of students considered most likely to be learning within level 1 of The New Zealand Curriculum for most of their time at school. Nevertheless, cautious notes need to be sounded on three counts. First, the key competencies have been developed within the framework of a sociocultural perspective of teaching and learning (Hipkins, 2007, 2009). For assessment to be meaningful, the key competencies need to also be assessed in a sociocultural framework. Without the professional learning that supports understanding and taking up a sociocultural view of teaching and learning, there is a very real danger that teachers and schools will return to the approaches with which they are already familiar and comfortable. One likely outcome is the development of checklist-type approaches to documenting the key competencies, divorced from their social contexts. Individual children will be measured on their ability to perform these competencies individually. The second caution is thus the possibility that the key competencies may become fragmented (Hipkins, 2007, 2009), divorced from the contexts of the learning areas in The New Zealand Curriculum.

The third caution is the continuing powerful influence of developmental and deficit discourses in the lives of students with special education needs. Narrative assessment, in the form of Learning Stories (Carr, 1998a, 1998b, 2001), has been used in early childhood settings for 10 years now. In the early days of the uptake of a narrative approach to assessment, a number of writers noted the difficulty early childhood educators had making the shift from pedagogy and assessment grounded in developmentally appropriate practices (e.g., Cullen, 2003; Nuttall, 2003). In some centres 
these difficulties reconceptualising assessment and pedagogy continue (e.g., Turnock, 2009). Dunn (2004) looked at the early childhood education experiences of young disabled children. She described the foundations and practices of early intervention therapists in these early childhood education settings. She noted the alignments, tensions and contradictions in practices between the early childhood educators and early intervention therapists, summarised in the title of her paper "Two constructs in one context". More recently, Macartney $(2008,2009)$ and Macartney and Morton (in press) have pointed out that the presence of Learning Stories is not a guarantee that the practices of assessment and pedagogy, based on developmental psychology, won't continue to work as mechanisms of exclusion in early childhood and school settings.

Clearly then, narrative assessment on its own will not be able to overcome those deficit discourses of difference and the discourses of individual pathology that continue to circulate within schools. Yet narrative assessment may help to resist and to potentially transform these deficit discourses to discourses of belonging and of competence. Narrative assessment may help teachers to move from pedagogical discourses of deviance to pedagogical discourses of inclusion (Skidmore, 2002). Combined with opportunities to work as members of learning communities (communities that include students, their families and educators), narrative assessment can provide all the learners and teachers in that community with the chance to see and be seen as active and competent learners, actively contributing to the life of classrooms and schools.

\section{Acknowledgments}

The New Zealand Curriculum Exemplars for Learners with Special Education Needs and the accompanying resource, Narrative Assessment: A Guide for Teachers, were developed by the University of Canterbury College of Education and Education Plus under contract to the Ministry of Education (www.throughdifferenteyes.org.nz). The analyses and interpretations in this article are solely those of the authors. Thank you to the teacher-writers and their students who together are the heart and soul of the exemplars. 


\section{References}

Brantlinger, E. (2000). Using ideology: Cases of the nonrecognition of the politics of research and practice in special education. In S. J. Ball (Ed.), Sociology of education: Major themes (pp. 1066-1106). London: RoutledgeFalmer.

Broadfoot, P. (2007). An introduction to assessment. New York: Continuum.

Carr, M. (1998a). Assessing children's experiences in early childhood: Final report to the Ministry of Education (Part one). Wellington: Ministry of Education.

Carr, M. (1998b). Assessing children's learning in early childhood settings. Wellington: New Zealand Council for Educational Research.

Carr, M. (2001). Assessment in early childhood settings: Learning stories. London: Paul Chapman.

Cowie, B. (2009). Teacher formative assessment and decision making: A consideration of principles and consequences. Assessment Matters, 1, 47-63.

Cowie, B., \& Carr, M. (2009). The consequences of sociocultural assessment. In A. Anning, J. Cullen, \& M. Fleer (Eds.), Early childhood education: Society and culture (pp. 95-106). London: Sage.

Cullen, J. (2003). The challenge of Te Whāriki: Catalyst for change? In J. Nuttall (Ed.), Weaving Te Whāriki: Aotearoa New Zealand's early childhood curriculum document in theory and practice (pp. 269-296). Wellington: New Zealand Council for Educational Research.

Danforth, S., Taff, S., \& Ferguson, P. M. (2006). Place, profession and program in the history of special education. In E. A. Brantlinger (Ed.), Who benefits from special education? Remediating (fixing) other people's children (pp. 1-25). Mahwah, NJ: Lawrence Erlbaum.

Dunn, L. 2004. Developmental assessment and learning stories in inclusive early intervention programmes: Two constructs in one context. New Zealand Research in Early Childhood Education, 7(1), 119-131.

Gipps, C. (1994). Beyond testing. Towards a theory of educational assessment. London: Falmer.

Gordon, L., \& Morton, M. (2008). Inclusive education and school choice in New Zealand: Democratic rights in a devolved system. In S. Gabel \& S. Danforth (Eds.), Disability and the politics of education: An international reader (pp. 237-250). New York: Peter Lang.

Graham, L. J. (2008). ADHD and schooling: Looking for better ways forward. International Journal of Inclusive Education, 12(1), 1-6.

Hatherly, A., \& Richardson, C. (2007). Building connections: Assessment and evaluation revisited. In L. Keesing-Styles \& H. Hedges (Eds.), Theorising early childhood practice: Emerging dialogues (pp. 51-70). Castle Hill, NSW: Pademelon Press. 
Hill, M. (2003). Assessment in the real world: What teachers actually do in the classroom. NZEI Occasional Papers. Wellington: New Zealand Educational Institute.

Hill, M. (2009). Ways of seeing: Using ethnography and Focault's 'toolkit' to view assessment practices differently. Qualitative Research, 9(3), 309-330.

Hipkins, R. (2007). Assessing the key competencies: Why would we? How could we? Wellington: Learning Media.

Hipkins, R. (2009). Determining meaning for key competencies via assessment practices. Assessment Matters, 1, 4-19.

James, M. (2006). Assessment, teaching and theories of learning. In J. Gardner (Ed.), Assessment and learning (pp. 47-60). London: Sage.

Kearney, A. C. (2008). Exclusion at school: What is happening for students who are disabled? The International Journal of Diversity in Organisations, Communities and Nations, 7(6), 220-227.

MacArthur, J. (2005). Tensions and conflicts: Experiences in parent and professional worlds. In L. Ware (Ed.), The politics of inclusion. Rochester, NY: Margaret Warner Graduate School, University of Rochester.

Macartney, B. (2008). Disabled by the discourse: Some impacts of normalising mechanisms in education and society on the lives of disabled children and their families. New Zealand Research in Early Childhood Education, 11, 33-50.

Macartney, B. (2009). Understanding and responding to the tensions between deficit discourses and inclusive education. set: Research Information for Teachers, 1, $19-27$.

Macartney, B. (2010). Living on the edge of the normal curve: "It's like a smack in the head." In C. Dudley-Marling \& A. Gurn (Eds.), The myth of the normal curve (pp. 205-219). New York: Peter Lang.

Macartney, B., \& Morton, M. (in press). Kinds of participation: Teacher and special education perceptions and practices of 'inclusion' in early childhood and primary school settings. International Journal of Inclusive Education.

McMenamin, T., Millar, R., Morton, M., Mutch, C., Nuttall, J., \& Tyler-Merrick, G. (2004). Final report to the Ministry of Education on curriculum policy and special education support. Wellington: Ministry of Education.

Millar, R., \& Morton, M. (2007). Bridging two worlds: Special education and curriculum policy. International Journal of Inclusive Education, 11(2), 163-176. doi: 10.1080/13603110500375382

Ministry of Education. (2007). The New Zealand curriculum. Wellington: Learning Media.

Ministry of Education. (2009a). The New Zealand curriculum exemplars for learners with special education needs. Wellington: Learning Media.

Ministry of Education. (2009b). Narrative assessment: A guide for teachers. Wellington: Learning Media. 
Morton, M. (in press). Using DSE to 'notice, recognize and respond' to tools of exclusion and opportunities for inclusion in New Zealand. Review of Disability Studies.

Morton, M., \& McMenamin, T. (2011). Learning together: Collaboration to develop curriculum assessment that promotes belonging. Support for Learning, 26(3), $109-114$.

Nuttall, J. (Ed.). (2003). Weaving Te Whäriki: Aotearoa New Zealand's early childhood curriculum document in theory and practice. Wellington: New Zealand Council for Educational Research.

Paugh, P. C., \& Dudley-Marling, C. (2011). "Speaking" deficit into (or out of) existence: How language constrains classroom teachers' knowledge about instructing diverse learners. International Journal of Inclusive Education, 15(8), 819-834.

Skidmore, D. (2002). A theoretical model of pedagogical discourse. Disability, Culture and Education, 1(2), 119-131.

Slee, R. (2011). The irregular school: Exclusion, schooling and inclusive education. London: Routledge.

Smith, D. G. (2004). Identity, self and other in the conduct of pedagogical action: An East/West inquiry. In W. Pinar (Ed.), Contemporary discourse: Twenty years of $J C T$ (pp. 458-473). New York: Peter Lang.

Smith, R., \& Barr, S. (2008). Towards educational inclusion in a contested society: From critical analysis to creative action. International Journal of Inclusive Education, 12(4), 401-422.

Turnock, K. (2009). "It's a shift in thinking, a shift in practice" Moving to a new assessment framework in early childhood education. Unpublished master's thesis, University of Canterbury, Christchurch.

Valle, J., \& Connor, D. (2011). Rethinking disability: A disability studies approach to inclusive practices. New York: McGraw-Hill.

Willis, J. (2010). Assessment for learning as a participative pedagogy. Assessment Matters, 2, 64-83.

\section{Note}

1 The previous name for ORS, current at the time of the research project.

\section{The authors}

Missy Morton and Trish McMenamin are senior lecturers in the School of Educational Studies and Human Development at the University of Canterbury.

Missy's areas of research and teaching include curriculum, assessment and pedagogy for students with disabilities; disability studies in education; inclusive education; and qualitative research.

Email: missy.morton@canterbury.ac.nz 
Morton, McMenamin, Moore and Molloy

Trish's areas of research are policies and practices in inclusive and special education. Email: trish.mcmenamin@canterbury.ac.nz

Geoff Moore is the Director of Education Plus at the University of Canterbury.

Email: Geoff.moore@canterbury.ac.nz

Sue Molloy was an Assess to Learn facilitator at Education Plus at the University of Canterbury.

Email: sue.molloy15@gmail.com

All of the authors worked on The New Zealand Curriculum Exemplars for Learners with Special Education Needs project. 